American Journal of Economics and Business Administration 2 (1): 35-38, 2010

ISSN 1945-5488

(C) 2010 Science Publications

\title{
Impact of foreign Direct Investment on Shares Market Value in Amman Exchange Market
}

\author{
Mohammad I. Al-Halalmeh and Abedalsttar M. Sayah \\ Department of Finance and Administration, Al-Balqa' a Applied University, \\ Princess Alia University College, Amman, Jordan
}

\begin{abstract}
Problem statement: To examine the impact of foreign direct investment on share market value in Amman Exchange Market. The impact of foreign direct investment on shares market value $\mathrm{s}$ investigated in this study needs more research and should be made on long period for the purpose of generalizing the obtained results. Approach: A self administrated questionnaire that was developed based on previous studies and the relevant literature. 100 questionnaires were distributed over the research sample. Results: Foreign direct investment has a significant impact on shares market value in Amman Exchange Market and constitutes between 45-50\% of the market value. Conclusion: It can be concluded that foreign direct investment according to the achieved results can play a major role on shares priced in Amman Exchange Market. Reinforces the idea that foreign direct investment has various positive impacts on different areas.
\end{abstract}

Key words: Amman Exchange Market, foreign direct investment, market value

\section{INTRODUCTION}

Due to the recession experienced by the Jordanian economy in the eighties and early nineties of the last century, the government resorted to encourage investment in all forms and types. Investment is one of the most important economic activities, which constitutes a pillar of economic life, it is the essential foundation for sustainable growth and economic development of the country. The country has taken many government measures to encourage foreign investment in Jordan and the new legislation was enacted, including allowing foreign investors to invest in the stock market. Figures and statistics published by the Amman Financial Market on the movement of foreign investment in the market during the year (2007) showed a clear improvement in the value of This investment, is an indicator of confidence of nonJordanian investors the performance and profitability of Jordanian companies during the last years and future years and therefore strongly trust the Jordanian economy and the continuity of growth and development of their confidence and improve the investment environment in Jordan in particular and foreign investment has standards and conditions when investing in the shares of any company or market comes in the forefront of corporate profitability the attractive price and liquidity of equity and efficiency of the market and the level of disclosure and transparency and preservation of the rights of investors and dealers and the strength and growth of the economy and net foreign investment and can be said that the investment climate in Jordan attractive climate for domestic and foreign alike, as consistently invest in so many development projects which are new entries investment, as it has been to put some laws and regulations to encourage investment, where he worked to make a lot of incentives and exemptions for local and foreign investor, which would help in the development of this trend a reality in the future. There are several factors affecting the attraction of foreign investments to Jordan, including the economic, including the political. Since that win the confidence of foreign investors is not only the political stability of present and future and diminished risks of non-economic and political stability and strategic location of the Jordan, is a key incentive in attracting foreign investment.

This study attempts to shed light on the impact of foreign investment on the performance of the Amman Financial Market.

Statistics from the Amman Stock Exchange that the value of shares bought by non-Jordanian investors since the beginning of the year 2009 until the end of November amounted to (2015.4) million Diners, constituting 22.4\% of the total volume. The value of stocks sold by nonJordanian investors for the same period 2.0142 billion

Corresponding Author: Mohammad I. Al-Halalmeh, Department of Finance and Administration,

Al-Balqa'a Applied University, Princess Alia University College, Amman, Jordan 
Darns, so that the net non-Jordanian investment since the beginning of the year until the end of the month of October has risen by 1.1 million Diners, compared with a high of $\$ 270.9$ million Diners for the same period in 2008. The total value of purchases of Arab investors since the beginning of the year until the end of November 1.7842 billion, constituting $88.5 \%$ of the total purchase value of non-Jordanians, while the total value of purchases of non-Arabs during the same period 231.1 million, constituting $11.5 \%$ of the total purchases of non-Jordanian.

As for the total value of the sale of the Arabs has reached 1.7781 billion, constituting $88.3 \%$ of the total value of sales by non-Jordanians and the value of the sale of non-Arabs 236.2 million Diners, which represented $11.7 \%$ of the total sale value of nonJordanians.

The statistics also showed that of the stock market value of shares purchased by non-Jordanian investors that are made through trading on the Amman Stock Exchange during the month of November amounted to 54.5 million Diners, constituting $11.5 \%$ of the total trading volume, while the value of stocks sold before them, 60.5 million Diners and the net foreign investment has fallen by 6.0 million Diners during the month of November.

And it becomes Non-Jordanian ownership in companies listed on the Stock Exchange at the end of November approximately $48.3 \%$ of the total market value, accounting for the contribution of Arabs, 33.3\%, while the contribution of non-Arabs constituted $15.0 \%$ of the total market value of the Stock Exchange.

Foreign investment as an economic process aimed to create capital from establishing economic enterprises that provide different needs and achieving financial surpluses. Jordan Promotion Act No. (16) of 1995 defined foreign investment as follows: Invested foreign capital means for the purposes of this act what non Jordanian invest of cash or kind or equity that have financial value in the kingdom (Samerai, 2006).

Foreign direct investment is deemed as one of the important option for economic growth in not all developing countries. But to some extent, not all developing countries are equally open to foreign investment. Some countries restrict foreign equity, while others encourage investors to enter their markets. due to the fact that foreign direct investment involves investors enters national markets and profits, it is very political. Foreign direct investment may bring economic benefits, such as jobs and new technology, but it may also entail economic costs, such as increased competition for national businesses. In the same time foreign direct investment I may also bring political costs. Most governments have policies to control foreign direct investment entry into their markets. Foreign direct investment requires agreement between developing states and international investors and therefore agreements are reached with influence from domestic-level political and economic factors, as well as international level factors. It is worth to say that foreign investments have various advantages such as increasing the productivity and completion capability of local industries, increasing new job opportunity, increasing state reserves of foreign currency and other advantages (Saggi, 1999). All nations interested in attracting foreign direct investment exert their best efforts to present their investment environment such as financial environment, political situation, social stability and economic prosperous (Gorg, 2003). Most countries government provide incentives for attracting foreign direct investment such low taxes, allow foreigners majority ownership of projects, liberal employment of expatriates and other incentives.

\section{MATERIALS AND METHODS}

Collection of data required for the paper was divided in two parts: The secondary data was collected through using the reference, books, Internet and annual reports of Amman Exchange, while the primary data was collected through a self administrated questionnaire which was developed according to the objectives of the paper. The questionnaire consists of two sections. The first section comprises the main demographic of the sample, the second part of the questionnaire includes the related statements that measure the impact of foreign direct investment on shares market value in Amman Exchange Market. All items were measured by responses on a five-point Likert scale of agreement with statements, ranging from 1 strongly disagree to 5 strongly agree. The sample of this research consisted of all dealers and investors in Amman Exchange Market during the survey period, the sample was selected randomly over a period of one week from those who are attending daily operations in the market. About 60 questionnaires were delivered to selected respondents. Due to time limit, the questionnaires were completed on spot.

The collected data through the questionnaire was analyzed by using the Social Packaging Statistical System (SPSS), where frequencies, percentages were calculated for the first part of the questionnaire and means, standard deviations were calculated for the answers of the second part of the questionnaire. Multiple regression analysis was performed to predict the relationship between the foreign direct investment and shares market value. 
Advantages of foreign direct investment: Jackson (2008) views that foreign direct investment helps in job creations, increase wages, growth in the manufacturing sector, transfer new technologies and skills, increases labor productivity, increases tax returns and lower interest rates. Technology transfer between nations is deemed one of the most important roles that foreign direct investment can play either for developed or developing countries. Technology transfer can aid in research and development and in creating economies of scale (Saggi, 1999). Most nations view foreign direct investment as a part of beneficial of foreign capital because it is associated with a transfer of foreign technology and skills in areas like managerial techniques, marketing ideas, accounting practices and multiple other business-relevant. Almubarak (2009) indicated that developing countries are looking for foreign direct investment as a source of economic development, income growth and employment.

Foreign direct investment barriers: Bastova (2008) reported that foreign direct investment is affected by four major factors: the geographical location of the city country, the local economy the cultural background of the host country and economic policy, including openness to trade and foreign trade investment. Is also a major determinant in attracting foreign direct investment.

Nicoletti et al. (2003) reported border barriers have negative impact on foreign direct investment, while high quality of infrastructure in the host country attracts foreign direct investment. They added that high taxes hinder foreign direct investment. Marshall (2006) found that electoral rules and political stability in the host country impact politician's incentives to attract foreign direct investment argued that instability associated with investment risk is critical in explaining the level of FDI inflows to the Middle Eastern countries.

Foreign direct investment in Jordan: Table 1 indicates the size of foreign direct investment in Amman Exchange Market during the period 2006-2009 in million JD.

Table 1 shows that foreign direct investment in terms of purchasing or selling increased during the years 2007 and 2008. But in 2009 there was a sharp decline which can be attributed to international financial crisis.

Table 1: The size of foreign direct investment in Amman Exchange Market during the period 2006-2009 in million JD

\begin{tabular}{lllll}
\multicolumn{5}{c}{ Market during the period 2006-2009 in million JD } \\
\hline Year & Purchase & Selling & $\begin{array}{l}\text { Net } \\
\text { investment }\end{array}$ & $\begin{array}{l}\text { Market } \\
\text { value (\%) }\end{array}$ \\
\hline 2006 & 1.995 & 1.730 & 265 & 48.7 \\
2007 & 2.804 & 2.235 & 569 & 46.5 \\
2008 & 4.219 & 3.910 & 309 & 46.1 \\
2009 & 2.136 & 2.139 & 32 & 48.7 \\
\hline
\end{tabular}

Attracting foreign investment advantages for Jordan: Foreign direct investment advantages for Jordan can be summarized as follows (AlQashi, 2009):

- Foreign direct investments are considered a good source to obtain foreign currency and capitals that can support state development program

- Foreign direct investment may create good class of Jordanian business men

- Foreign direct investment creates work opportunities for Jordanian labors and as a result contributes in reducing unemployment rate

- Foreign direct investment in training Jordanian labor force and gaining experiences and skills

- Foreign direct investment contributes in opening new world markets for Jordanian goods

- $\quad$ Foreign direct investment contributes in providing services and goods of high quality

- Foreign direct investment in reducing moo in local market and creating strong competition that contributes in supporting product and service quality

- Foreign direct investment contributes in knowledge exchange between service and industrial sectors

- Foreign direct investment contributes in reducing trade balance deficient gap and payment balance

- Foreign direct investment contributes in reducing state budget deficient rate

- It contributes in increasing state economy growth rate

\section{RESULTS}

Demographic data show that the majority of respondents were males: 61.7 and $38.3 \%$ were female.

Just more than the half $(55 \%)$ were under 30 years of age, $40 \%$ between $31-40$ years and 5\% between $41-$ 50 years. Undergraduates accounted for $31.7 \%$. While graduates accounted for $68.3 \%$ of all respondents. About $20 \%$ of the sample was foreign investors, while $56 \%$ were local investors and $23.3 \%$ were business men.

Means of all statements were ranged between (3.25-4.13), which is more than the virtual mean (3), this means that respondents agree that foreign direct investment has an influence on share market value in Amman Exchange Market.

The results of t-test analysis confirm such results and show a significant impact of foreign direct investment and shares market value (Table 2).

Table 2: T-test results

\begin{tabular}{lll}
\hline T calculated & T tabulated & Sig \\
\hline 10.495 & 2.0096 & 0.000 \\
\hline
\end{tabular}


At 5\% significance level. Therefore, we can conclude that foreign direct investment influence Amman Exchange Market performance in terms of affecting shares market values. This gives the indication that the greater the size of foreign direct investment in Amman Exchange Market the higher the level of shares market value.

\section{DISCUSSION}

In order to create agood Investment environment I Jordan first of all, we should find an attractive in vestment climate, for domestic and the foreign, which is full of peace, stability. By making local labors conscious of how to deal with others and how to get benefits of their own experience, technology and how to create the best climate of willingness, co-operation and the partner ship between them.

I think that promoting foreign direct investment in Jordan will increase competition, productivity, new job opportunity and it can transfers new technology and skills. And we don't forget our human element as he or she is the essence of the investment we should pay a great emphasis on him by equipping and training him in order to cope up with all changes.

\section{CONCLUSION}

This study has demonstrated that foreign direct investment in Amman Exchange Market affect price of companies shares, since it increases the demand or the supply, therefore the prices are affected either positively or negatively. This also was confirmed from the obtained data from Amman Exchange Market were foreign direct investment constitute $45-50 \%$ of the shares market value.

\section{REFERENCES}

Almubarak, N.A., 2009. Determinants of foreign direct investment in the Kingdom of Saudi Arabia a cross country analysis. http://gradworks.umi.com/14/62/1462311.html

AlQashi, T., 2009. International accounting standards implementation impact on attracting foreign direct investment. Arabic J. Manage. http://www.worldacc.net/vb/t349.html
Bastova, M., 2008. Foreign direct investment effects on urban economy: A case of the city of Pilsen, Czech Republic. Master Thesis, University of Nebraska, USA. http://communicate.aag.org/eseries/aag_org/progra $\mathrm{m} /$ AbstractDetail.cfm?AbstractID $=18955$

Gorg, H., 2003. Foreign direct investment, investment incentives, and firing costs: A disadvantage for "inflexible Europe"? IDEAS. http://www.ucm.es/info/econeuro/documentos/doc umentos/dt302003.pdf

Jackson, J.K., 2008. Foreign direct investment in the United States: An economic analysis. http://fpc.state.gov/documents/organization/109490 .pdf

Marshall, G., 2006. The institutional determinants of foreign direct investment patterns: Evidence from the OECD. Proceeding of the Annual Meeting of the International Studies Association, Mar. 22, Town and Country Resort and Convention Center, San Diego, California, USA., pp: 1-38. http://www.allacademic.com/meta/p98276_index.h tml

Nicoletti, G., S.S. Golub, D. Hajkova, D. Mirza and K.Y. Yoo, 2003. The influence of policies on trade and foreign direct investment. OECD Economic Studies $\quad$ No. $\quad 36, \quad 2003 / 1$. http://www.oecd.org/dataoecd/22/2/33638319.pdf

Saggi, K., 1999. Trade foreign direct investment and international technology transfer: A survey. http://papers.ssrn.com/sol3/papers.cfm?abstract_id $=630721$

Samerai, D., 2006. Foreign investment: Barriers and legal guarantees. Arab Unity Studies Center. http://www.caus.org.lb/Home/publication_popup.p $\mathrm{hp} ? \mathrm{ID}=3598 \& \mathrm{~h}=1$ 